\title{
Studies on the Formation of Bacitracin by Bacillus licheniformis: Role of Catabolite Repression and Organic Acids
}

\author{
By H. I. HAA VIK \\ Department of Research and Development, A/S Apothekernes \\ Laboratorium for Specialpraparater, Oslo, Norway
}

(Received I6 May I974; revised I9 June I974)

\begin{abstract}
SUMMAR Y
Bacitracin production by Bacillus licheniformis ATCCI07I6 is markedly inhibited by glucose. This inhibitory effect is due to the lowered $\mathrm{pH}$ and undissociated organic acids produced by the metabolism of glucose. The possibility that catabolite repression is an incidental result of low $\mathrm{pH}$ and the production of organic acids from glucose during growth is discussed.
\end{abstract}

\section{INTRODUCTION}

Since the initial observation by Epps \& Gale (1942), the inhibitory effect of glucose and related compounds upon a variety of microbial enzymes has been reported by numerous investigators. An excellent review is given by Paigen \& Williams (1970). This glucose effect was termed catabolite repression by Magasanik (I96I) who postulated that the phenomenon was a regulatory mechanism, a view which has found general acceptance (Mandelstam, 1962; Moses \& Prevost, I966; Demain, I968; Schaeffer, I969; Gallo \& Katz, I972; Meers, 1972).

The mechanism of catabolite repression is not completely understood. The phenomenon involves interference with the induction of certain enzymes by the catabolites of a rapidly used carbon source. The catabolites which are supposed to interfere are termed effectors, although the effector has not been positively identified in any system (Paigen $\&$ Williams, 1970).

Bacitracin production by Bacillus licheniformis is reported to be controlled by catabolite repression due to glucose (Laishley \& Bernlohr, 1968). The inhibitory effect of glucose upon bacitracin formation by $B$. licheniformis has been examined and the results are discussed in this paper.

\section{METHODS}

Organism. The bacitracin-producing strain of B. licheniformis ATCCI07I6 was kept as a spore suspension at $4{ }^{\circ} \mathrm{C}$ throughout the investigation.

Media and growth conditions. The chemically defined media, M2 and M2O, used for growth and bacitracin production are described by Haavik (1974a). The inoculum consisted of spores.

Microbial assay of bacitracin. Bacitracin was determined by an agar diffusion method according to Haavik \& Thomassen (1973).

Growth. Bacterial growth was measured as extinction at $650 \mathrm{~nm}$ using a Spectronic 20 spectrophotometer. Before $E_{650}$ was measured, the culture fluid was appropriately diluted with distilled water. Growth was then expressed as $E_{650} \times$ dilution factor. Growth measured 
Table I. Effect of glucose upon bacitracin production by Bacillus licheniformis in M20 medium

\begin{tabular}{|c|c|c|c|c|c|c|}
\hline \multirow[b]{2}{*}{$\begin{array}{l}\text { Time of } \\
\text { incubation (h) }\end{array}$} & \multicolumn{3}{|c|}{ Glucose absent } & \multicolumn{3}{|c|}{ Glucose $(1 \cdot 0 \%)$} \\
\hline & $\begin{array}{c}\text { Growth } \\
\left(E_{650}\right)\end{array}$ & $\mathrm{pH}$ & $\begin{array}{l}\text { Bacitracin } \\
\text { (i.u./ml) }\end{array}$ & $\begin{array}{c}\text { Growth } \\
\left(E_{650}\right)\end{array}$ & $\mathrm{pH}$ & $\begin{array}{c}\text { Bacitracin } \\
\text { (i.u. } / \mathrm{ml})\end{array}$ \\
\hline 10 & 0.32 & $7 \cdot 58$ & 0.2 & 0.30 & 6.90 & n.d. \\
\hline I I & 0.62 & $7 \cdot 75$ & 0.4 & 0.68 & $6 \cdot 50$ & n.d. \\
\hline 12 & $1 \cdot 10$ & $7 \cdot 93$ & 0.5 & $1 \cdot 20$ & $5 \cdot 84$ & n.d. \\
\hline 13 & $\mathbf{I} \cdot 70$ & $7 \cdot 98$ & $I \cdot I$ & $2 \cdot 00$ & $5 \cdot 50$ & n.d. \\
\hline 14 & $2 \cdot 35$ & 8.06 & $2 \cdot 4$ & $2 \cdot 60$ & $5 \cdot 46$ & n.d. \\
\hline 16 & $3 \cdot 90$ & $8 \cdot 26$ & $4 \cdot 2$ & 4.43 & $5 \cdot 52$ & 0.3 \\
\hline 18 & 5.90 & $8 \cdot 35$ & $8 \cdot 0$ & $6 \cdot 00$ & $6 \cdot 30$ & 1.8 \\
\hline 20 & $7 \cdot 40$ & $8 \cdot 44$ & IO'I & $7 \cdot 20$ & $7 \cdot 00$ & $3 \cdot 8$ \\
\hline 22 & $8 \cdot 64$ & $8 \cdot 60$ & $10 \cdot 8$ & $8 \cdot 45$ & $7 \cdot 28$ & 6.0 \\
\hline 24 & $9 \cdot 55$ & $8 \cdot 82$ & I $1 \cdot 4$ & $9 \cdot 90$ & $7 \cdot 50$ & $10 \cdot 1$ \\
\hline 26 & $9 \cdot 60$ & 8.90 & $12 \cdot 0$ & 10.00 & $7 \cdot 85$ & 10.0 \\
\hline 28 & $8 \cdot 50$ & $9 \cdot 20$ & $8 \cdot 3$ & $9 \cdot 80$ & $8 \cdot 10$ & $8 \cdot 0$ \\
\hline
\end{tabular}

in this manner showed an excellent correlation with bacterial viability (Haavik, 1974b). Bacterial viability was determined by spreading a suitable dilution of the culture upon nutrient agar (Difco) plates and counting the colonies formed after $24 \mathrm{~h}$ of incubation at $37^{\circ} \mathrm{C}$.

Determination of organic acids in the fermentate. The bacteria were removed by sterile filtration (Millipore type HA, $0.45 \mu \mathrm{m}$ ). The filtrate was acidified with $\mathrm{I} \mathrm{M}-\mathrm{HCl}$ to $\mathrm{pH} 2 \cdot 0$, and the organic acids extracted with ether. The ether fraction was evaporated to dryness, and the residue was redissolved in chloroform. Samples from this solution were injected into the gas chromatograph (Varian Gas Chromatograph I400). The column was a I.8 $\mathrm{m}$ coiled-steel column (3.2 mm inside diam) filled with Porapack Q (80 to 100 mesh, Waters Ass. Inc., Massachusetts, U.S.A.). The column temperature was $200{ }^{\circ} \mathrm{C}$. The compounds were detected by a flame ionization detector. The peaks were identified by running authentic compounds both separately and together with the sample. Acetic acid was the only acid detected by this method. Pyruvate was determined enzymically in the filtrate with a Biochemica Test Combination (Boehringer, Mannheim, Germany).

\section{RESULTS}

\section{Effect of glucose and $\mathrm{CaCO}_{3}$}

Bacitracin production closely paralleled growth in the medium without glucose, but was markedly retarded when glucose ( $\mathrm{I} \%$ ) was added (Table $\mathrm{I}$ ). $\mathrm{pH}$ decreased during the first period of growth when glucose was a constituent of the medium.

Analysis of the culture filtrate revealed that the $\mathrm{pH}$ drop was due to the presence of acetic and pyruvic acids. This is in agreement with Speck \& Freese (1973) who examined acid production from glucose by Bacillus subtilis.

When the culture fluid was neutralized with $\mathrm{CaCO}_{3}$, both the drop in $\mathrm{pH}$ and the inhibition of bacitracin production by glucose were prevented (Haavik, I974a). 


\section{Effect of organic acids and low $\mathrm{pH}$}

When the $\mathrm{pH}$ of the culture fluid was lowered to about 5.5 with sterile hydrochloric acid (I M) $12 \mathrm{~h}$ after the initiation of growth in the M20 medium without glucose, bacitracin production was not inhibited (Table 2). However, when the $\mathrm{pH}$ was lowered to about 5.5 with a mixture of acetic and pyruvic acids (about $0.3 \mathrm{ml}$ of a $\mathrm{I}: \mathrm{I}$ by volume mixture of concentrated acids was added to $60 \mathrm{ml}$ culture fluid), bacitracin production was markedly inhibited (Table 2).

When acetate and pyruvate $(5.0 \mathrm{~g}$ of each $/ \mathrm{l})$ were added to the M20 medium at neutral conditions a few hours after the initiation of growth, bacitracin production was not inhibited (Table 2).

Epps \& Gale (1942) examined the effect of low pH upon several enzyme activities by using a phthalate buffer medium of $\mathrm{pH} 5.0$. Therefore $0.5 \%(\mathrm{w} / \mathrm{v})$ phthalic acid was introduced into the M20 medium and the $\mathrm{pH}$ was then lowered with either hydrochloric acid or a mixture of acetic and pyruvic acids. Bacitracin production was only inhibited when the $\mathrm{pH}$ was lowered with acetic and pyruvic acids (Table 3 ). The inclusion of phthalic acid had no effect.

When the $\mathrm{pH}$ was lowered to 5.5 with acetic acid alone $(0.3 \mathrm{ml} / 60 \mathrm{ml}$ culture fluid), both bacitracin production and growth were severely inhibited. When the $\mathrm{pH}$ was lowered to 5.5 with pyruvic acid alone (about $0.3 \mathrm{ml} / 60 \mathrm{ml}$ culture fluid) only bacitracin production was inhibited (Table 4).

\section{DISCUSSION}

Bacitracin production was inhibited when glucose was added to the medium, an effect also shown by Laishley \& Bernlohr (1968) who suggested that bacitracin production is controlled by catabolite repression by glucose. The inhibitory effect of glucose, however, can be prevented by neutralizing the culture fluid with $\mathrm{CaCO}_{3}$ (Haavik, 1974a), which indicates that the effect of glucose upon bacitracin production might simply be an effect of the low $\mathrm{pH}$ produced by glucose metabolism.

It is generally believed that the glucose effect or catabolite repression is not an incidental result of acid production, although a drop in $\mathrm{pH}$ is frequently observed as the glucose is metabolized (Paigen \& Williams, 1970). This belief is mainly based on the work of Epps \& Gale (1942) who examined the effect of low $\mathrm{pH}$ and glucose upon several enzyme activities of Escherichia coli. When glucose was added to their medium, the $\mathrm{pH}$ dropped to about 5.0 during its consumption. However, a comparison of organisms grown in a medium maintained at $\mathrm{pH} 5.0$ with those grown in a glucose medium revealed a marked inhibition of several enzyme activities in the glucose medium as compared with the low $\mathrm{pH}$ medium, and they concluded that glucose has an inhibitory effect on the enzyme activities far greater than any effect that can be ascribed to $\mathrm{pH}$.

Epps \& Gale (1942) did not determine which acids from glucose metabolism caused the drop in $\mathrm{pH}$, and they made a low $\mathrm{pH}$ medium by the addition of phthalic acid buffer. Consequently they compared the effect of some unknown organic acids from glucose metabolism with the effect of phthalic acid upon the enzyme activities at $\mathrm{pH} 5.0$. We have examined the effect of low $\mathrm{pH}$ upon bacitracin production by lowering the $\mathrm{pH}$ with the organic acids actually formed as the glucose is metabolized by the bacteria. The low $\mathrm{pH}$ resulting from the addition of acetic acid and pyruvic acid produced a marked inhibition of bacitracin production, whereas a low $\mathrm{pH}$ produced by an inorganic acid $(\mathrm{HCl})$ and phthalic 


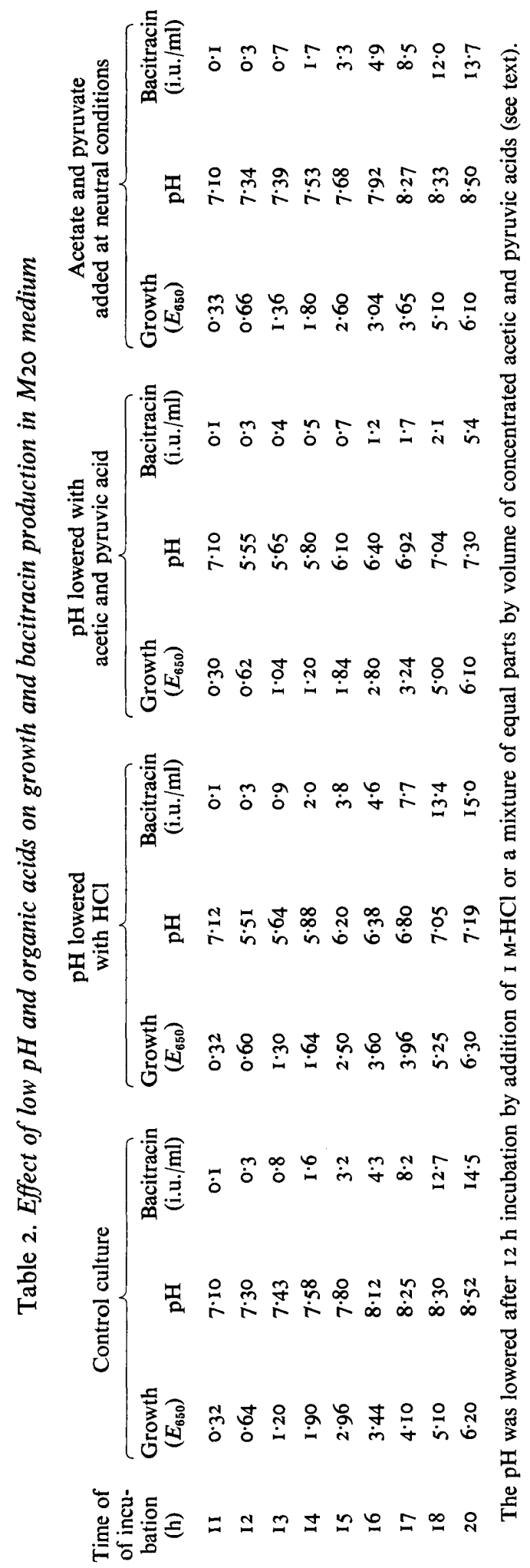


Table 3 . Effect of low $\mathrm{pH}$ and organic acids on growth and bacitracin production when phthalic acid (0.5\%) is a constituent of the medium

\begin{tabular}{|c|c|c|c|c|c|c|}
\hline \multirow{2}{*}{$\begin{array}{l}\text { Time of } \\
\text { incubation } \\
\text { (h) }\end{array}$} & \multicolumn{3}{|c|}{ pH lowered with $\mathrm{HCl}$} & \multicolumn{3}{|c|}{$\begin{array}{l}\text { pH lowered with } \\
\text { acetic and pyruvic acids }\end{array}$} \\
\hline & $\begin{array}{l}\text { Growth } \\
\left(E_{650}\right)\end{array}$ & $\mathrm{pH}$ & $\begin{array}{l}\text { Bacitracin } \\
\text { (i.u./ml) }\end{array}$ & $\begin{array}{l}\text { Growth } \\
\left(E_{650}\right)\end{array}$ & $\mathrm{pH}$ & $\begin{array}{r}\text { Bacitracin } \\
\text { (i.u./ml) }\end{array}$ \\
\hline 12 & 0.86 & $5 \cdot 62$ & 0.3 & 0.84 & $5 \cdot 68$ & 0.2 \\
\hline 13 & I'I4 & 5.68 & 0.7 & I $\cdot 04$ & $5 \cdot 72$ & 0.2 \\
\hline 14 & $I \cdot 70$ & $5 \cdot 75$ & $I \cdot 3$ & I 50 & 5.80 & 0.3 \\
\hline 15 & $2 \cdot 30$ & 5.95 & $2 \cdot 0$ & 2.00 & 5.90 & 0.6 \\
\hline 16 & $3 \cdot 16$ & $6 \cdot 12$ & 4.5 & $2 \cdot 86$ & 6.00 & I.O \\
\hline 17 & $3 \cdot 84$ & 6.52 & $7 \cdot 2$ & 3.66 & $6 \cdot 25$ & $1 \cdot 3$ \\
\hline 20 & $6 \cdot 10$ & 6.90 & I 2.5 & 6.04 & 6.37 & $3 \cdot 2$ \\
\hline 24 & $8 \cdot 20$ & $7 \cdot 20$ & $14^{\circ}$ & 8.15 & $6 \cdot 78$ & 4.5 \\
\hline
\end{tabular}

The $\mathrm{pH}$ was lowered after $\mathrm{I} 2 \mathrm{~h}$ incubation by addition of $\mathrm{I} \mathrm{M}-\mathrm{HCl}$ or a mixture of equal parts by volume of concentrated acetic and pyruvic acids (see text).

Table 4. Effect of acetic acid or pyruvic acid and low pH on growth and bacitracin production

$\begin{array}{ccccccc}\begin{array}{c}\text { Time of } \\ \text { incubation } \\ \text { (h) }\end{array} & \begin{array}{c}\text { Growth } \\ \left(E_{650}\right)\end{array} & \mathrm{pH} & \begin{array}{c}\text { Bacitracin } \\ (\text { i.u./ml) }\end{array} & \begin{array}{c}\text { Growth } \\ \left(E_{650}\right)\end{array} & \mathrm{pH} & \begin{array}{c}\text { Bacitracin } \\ \text { (i.u./ml) }\end{array} \\ \text { I2 } & 0.80 & 5.60 & 0.2 & 0.89 & 5.55 & 0.3 \\ \text { I3 } & 0.80 & 5.58 & 0.3 & 1.24 & 5.83 & 0.3 \\ \text { I4 } & 0.84 & 5.62 & 0.3 & 2.14 & 5.95 & 0.6 \\ \text { I5 } & 0.88 & 5.60 & 0.3 & 2.84 & 6.20 & 0.9 \\ \text { I6 } & 0.79 & 5.63 & 0.3 & 3.59 & 6.34 & 1.3 \\ \text { I7 } & 0.98 & 5.66 & 0.4 & 4.40 & 6.42 & 2.5\end{array}$

The pH was lowered to about 5.5 with concentrated acetic acid or concentrated pyruvic acid $12 \mathrm{~h}$ after the initiation of growth.

acid had no inhibitory effect. This indicates that the inhibitory effect of glucose upon bacitracin production was due to the organic acids produced from glucose metabolism.

Acetate and pyruvate have no inhibitory effect upon bacitracin production when added at neutral pH. Consequently the organic acids inhibit only in an acidic environment. Dagley, Dawes \& Foster (1953) showed that the toxicity of organic acids is pH-dependent. They observed that the total growth was dependent on the initial $\mathrm{pH}$ of the medium: lower initial $\mathrm{pH}$ resulted in low total growth.

Our data indicate that the effect of low $\mathrm{pH}$ is dependent on the acid used to lower the $\mathrm{pH}$. Total growth was not influenced by lowering the $\mathrm{pH}$ to 5.5 except when acetic acid was added, causing severely inhibited growth.

Organic acids exist in their undissociated state at low $\mathrm{pH}$ values; such undissociated small molecules penetrate the bacterial membrane relatively easily and hence create a low internal $\mathrm{pH}$ upon dissociation. This lower internal $\mathrm{pH}$ is probably strongly inhibitory to bacitracin production, in agreement with Ishihara, Sasaki \& Shimura (I968) who found an optimum $\mathrm{pH}$ of $7 \cdot 4$ for the incorporation of radioactive histidine into bacitracin by a cell-free preparation. At lower $\mathrm{pH}$, markedly less histidine was incorporated. This may explain why both organic acids and low $\mathrm{pH}$ are required to inhibit bacitracin formation.

Since acetic acid has a higher dissociation constant than pyruvic acid, more undissociated 
molecules of acetic acid than of pyruvic acid are present in the medium at $\mathrm{pH} 5.5$. Acetic acid is therefore able to create a lower internal $\mathrm{pH}$ than pyruvic acid. Bacitracin production is more sensitive to low $\mathrm{pH}$ than is growth (Haavik, 1974a). This may explain why acetic acid added to $\mathrm{pH} 5.5$ inhibits both growth and bacitracin production, whereas pyruvic acid only inhibits bacitracin production.

Since the breakdown of glucose or other rapidly metabolized carbohydrates is often associated with a drop in $\mathrm{pH}$ due to the formation of organic acids, in some cases the glucose effect or catabolite repression may simply be an incidental inhibitory effect of low $\mathrm{pH}$ and undissociated organic acids.

I am grateful to Mr T. Höyland, Director of Research and Development, for his support of this work, to Mr S. Thomassen and Dr H. P. Throndsen for critically reading the manuscript, and to Mrs Eva Gustavsson for skilled assistance with the experimental work.

\section{REFERENCES}

Dagley, S., DAwes, E. A. \& Foster, S. M. (1953). The influence of pH value and aeration on the growth of Aerobacter aerogenes and Bacterium coli in defined media. Journal of General Microbiology 8, 314-322.

DEMAIN, A. L. (1968). Regulatory mechanisms and the industrial production of microbial metabolites. Lloydia 3I, 395-418.

Epps, H. M. R. \& GALE, E. F. (I942). The influence of the presence of glucose during growth on the enzymic activities of Escherichia coli: comparison of the effect with that produced by fermentation acids. Biochemical Journal 36, 619-623.

Gallo, M. \& KATZ, E. (1972). Regulation of secondary metabolite biosynthesis: catabolite repression of phenoxazinone synthase and actinomycin formation by glucose. Journal of Bacteriology ro9, 659-667.

HAAVIK, H. I. (1974a). Studies on the formation of bacitracin by Bacillus licheniformis: effect of glucose. Journal of General Microbiology 81, 383-390.

HAAVIK, H. I. (1974b). Studies on the formation of bacitracin by Bacillus licheniformis: effect of inorganic phosphate. Journal of General Microbiology 84, 226-230.

HaAvik, H. I. \& Thomassen, S. (I973). A bacitracin-negative mutant of Bacillus licheniformis which is able to sporulate. Journal of General Microbiology 76, 45I-454.

IshiHARA, H., SASAKI, T. \& SHIMURA, K. (I968). Biosynthesis of bacitracin. II. Incorporation of ${ }^{14} \mathrm{C}-$ labelled amino acids into bacitracin by a cell-free preparation from Bacillus licheniformis. Biochimica et biophysica acta r66, 496-504.

LAISHLEY, E. J. \& BERNLOHR, R. W. (1968). Regulation of arginine and proline catabolism in Bacillus licheniformis. Journal of Bacteriology 96, 322-329.

MagasaniK, B. (196I). Catabolite repression. Cold Spring Harbor Symposium on Quantitative Biology 26, 249-256.

MANDELSTAM, J. (1962). The repression of constitutive $\beta$-galactosidase in Escherichia coli by glucose and other carbon sources. Biochemical Journal 82, 489-493.

MEERS, J. L. (1972). The regulation of $\alpha$-amylase production in Bacillus licheniformis. Antonie van Leeuwenhoek 38, 585-590.

Moses, V. \& Prevost, C. (1966). Catabolite repression of $\beta$-galactosidase synthesis in Escherichia coli. Biochemical Journal roo, 336-353.

Paigen, K. \& Williams, B. (1970). Catabolite repression and other control mechanisms in carbohydrate utilization. Advances in Microbial Physiology 4, 25I-324.

SCHAEFFER, P. (1969). Sporulation and the production of antibiotics, exoenzymes and exotoxins. Bacteriological Reviews 33, 48-71.

SPECK, E. L. \& FreEse, E. (1973). Control of metabolite secretion in Bacillus subtilis. Journal of General Microbiology 78, 26I-275. 